\title{
Formaldehyde catalytic oxidation over hydroxyapatite modified with various organic molecules
}

\author{
Yahui Sun a, Zhenping $\mathrm{Qu}^{\mathrm{a}}{ }^{\mathrm{a},}$, Dan Chen a, Hui Wang a, Fan Zhang b, Qiang Fu ${ }^{\mathrm{b}}$ \\ ${ }^{a}$ Key Laboratory of Industrial Ecology and Environmental Engineering (MOE), School of Environmental Science and Technology, Dalian University of \\ Technology, Dalian116024, Liaoning, China \\ b State Key Laboratory of Catalysis, Dalian Institute of Chemical Physics, Chinese Academy of Sciences, Dalian 116023, Liaoning, China
}

\section{A R T I C L E I N F O}

Article history:

Received 13 April 2014

Accepted 28 April 2014

Published 20 December 2014

Keywords:

Modified hydroxyapatite

Sodium citrate

Specific surface area

Hydroxyl group

Formaldehyde catalytic oxidation

\section{A B S T R A C T}

Hydroxyapatite (HAP) was modified by adding various organic molecules, such as cetyltrimethylammonium bromide, sodium dodecyl sulfate, and sodium citrate, during the precipitation of HAP. Sodium citrate-modified HAP displayed the best activity for formaldehyde oxidation, achieving complete conversion at $240{ }^{\circ} \mathrm{C}$. The influence of the organic modifiers on the structure of HAP was assessed by X-ray diffraction, Fourier transform infrared spectroscopy, $\mathrm{N}_{2}$ adsorption-desorption, scanning electron microscopy, and thermogravimetry/derivative thermogravimetry. The higher specific surface area and pore volume, and smaller pores, owing to modification with sodium citrate, favored adsorption, mass transfer, and interaction process during formaldehyde oxidation. Furthermore, the higher hydroxyl group content observed in sodium citrate-modified HAP enhanced interactions between formaldehyde and HAP, thus resulting in higher catalytic activity.

(C) 2014, Dalian Institute of Chemical Physics, Chinese Academy of Sciences. Published by Elsevier B.V. All rights reserved.

\section{Introduction}

As one of the most common volatile organic compounds, formaldehyde (HCHO) is generating increasing attention as it poses potential health risks to humans even at low concentrations. Thus, the removal of HCHO has become an important issue [1,2]. Numerous studies have been carried out for the abatement of HCHO; the main techniques being investigated are adsorption, plasma decomposition, biological/botanical filtration, and catalytic oxidation [1]. Among all these techniques, catalytic oxidation is a promising method for $\mathrm{HCHO}$ removal because of its efficiency, convenience, and no secondary pollution. Commonly studied catalysts include noble metals (e.g., Pt, $\mathrm{Au}, \mathrm{Pd}$, and $\mathrm{Ag}$ ) [3-6] and transition metal oxide catalysts (e.g., $\mathrm{MnO}_{x}$ and $\mathrm{CeO}_{2}$ ) [7-9]. Moreover, transition metal oxides are usually employed as substrate for loading noble metal catalysts [10-13]. Noble metal-loaded catalysts show relatively better activities towards $\mathrm{HCHO}$ oxidation (complete conversion is generally achieved at around $100{ }^{\circ} \mathrm{C}$ or below) $[5,14]$. However, the high cost of noble metal limits the wide practical application of noble metal catalysts. For transition metal oxides, complete $\mathrm{HCHO}$ conversion temperatures are generally above $100{ }^{\circ} \mathrm{C}$, and even above $200{ }^{\circ} \mathrm{C}$ under some circumstances $[7,9,13]$. Besides poor performance, the toxicity of some commonly used transition metal oxides $\left(\mathrm{MnO}_{x}\right)$ limits the application of such catalyst systems $[15,16]$. In recent years, many studies on HCHO catalytic oxidation have been conducted to improve the catalytic performance. However, the studied catalytic systems are still focused on noble metal catalysts and transition metal oxides such as $\mathrm{MnO}_{x}, \mathrm{Ag} / \mathrm{CeO}_{2}, \mathrm{Co}_{3} \mathrm{O}_{4}$, and

\footnotetext{
* Corresponding author. Tel: +86-15542663636 Fax: +86-411-84708083; E-mail: quzhenping@dlut.edu.cn This work was supported by the National Natural Science Foundation of China (21377016), the Fundamental Research Funds for the Central Universities (DUT13LK27), and the Program for Changjiang Scholars and Innovative Research Team in University (IRT_13R05). 
$\mathrm{Pt} / \mathrm{CeO}_{2}$ [17-22]. The drawbacks of such catalytic systems are yet to be addressed. Thus, economical, safe, and non-toxic novel materials are required for HCHO catalytic oxidation.

As the main inorganic component of natural bone and teeth, with a wide application in the field of biomedical materials as biological active materials, hydroxyapatite (HAP) is safe and non-toxic [23]. Moreover, unlike noble metals, HAP is a cheaper alternative. In 2010, Xu et al. [24] reported HAP as a promising novel, non-precious metal catalyst for HCHO combustion, whereby the hydroxyl groups bonded to the $\mathrm{Ca}^{2+}$ channels may act as active sites.

To date, the examination of HAP as a catalytic material for HCHO oxidation remains rare. However, as a novel, non-precious metal catalyst with demonstrated activity towards HCHO oxidation, HAP is worth exploring further. It is well known that the catalyst performance is closely related to its structure. Based on the reported study [1], HCHO adsorption and its interaction with the support are related to the HCHO oxidation process. In that case, larger adsorption areas and abundant interaction between the reaction gas and catalyst will be important for activity enhancement. Organic modifiers have been widely used in morphology- and size-controlled synthesis of nano-sized metals and inorganic materials, as well as for the generation of pores and vacancies in the structure [25-30]. To this effect, in this study, organic modifiers (i.e., cetyltrimethylammonium bromide (CTAB), sodium dodecyl sulfate (SDS), and sodium citrate (SC)) were employed during the synthesis of HAP to modify its structure. Various characterization techniques and subsequent activity tests were conducted to elucidate the structure-performance relationship.

\section{Experimental}

\subsection{Preparation of catalysts}

HAP powder was prepared through an aqueous precipitation-hydrothermal method using $\left(\mathrm{NH}_{4}\right)_{2} \mathrm{HPO}_{4}$ (AR, Kemiou Chemical Reagent Co., Ltd, Tianjin) and $\mathrm{Ca}\left(\mathrm{NO}_{3}\right)_{2} \cdot 4 \mathrm{H}_{2} \mathrm{O}$ (AR, Damao Chemical Reagent Factory, Tianjin) as precursors. Ammonia $\left(\mathrm{NH}_{3}\right)$ solution (AR, Sinopharm Chemical Reagent Co., Ltd, Shanghai) was used for $\mathrm{pH}$ adjustments during the precipitation process. A solution of $0.2 \mathrm{~mol} / \mathrm{L} \mathrm{Ca}\left(\mathrm{NO}_{3}\right)_{2} \cdot 4 \mathrm{H}_{2} \mathrm{O}(4.72 \mathrm{~g}$ in $100 \mathrm{~mL}$ deionized water) containing an organic modifier (5 wt\%, CTAB (AR, Sinopharm Chemical Reagent Co., Ltd, Shanghai), SDS (AR, Kemiou Chemical Reagent Co., Ltd, Tianjin), or SC (AR, Reagent No. 1 Factory of Shanghai Chemical Reagent Co., Ltd., Shanghai)) was stirred under a constant temperature of $40{ }^{\circ} \mathrm{C}$. A solution of $0.3 \mathrm{~mol} / \mathrm{L}\left(\mathrm{NH}_{4}\right)_{2} \mathrm{HPO}_{4}(1.58 \mathrm{~g}$ in $40 \mathrm{~mL}$ deionized water) was added dropwise to the $\mathrm{Ca}\left(\mathrm{NO}_{3}\right)_{2} \cdot 4 \mathrm{H}_{2} \mathrm{O}$ solution. Then, the $\mathrm{pH}$ of the suspension was adjusted to 10 with ammonia solution (35\%), followed by $8 \mathrm{~h}$ of reaction under stirring. Subsequently, the reaction solution was transferred to a Teflon-lined autoclave and heated at $100{ }^{\circ} \mathrm{C}$ for $12 \mathrm{~h}$. Finally, the resulting powders were centrifuged and washed multiple times and dried at $100{ }^{\circ} \mathrm{C}$ overnight and then calcined at $700{ }^{\circ} \mathrm{C}$ for $2 \mathrm{~h}$. The obtained HAP samples were denoted as

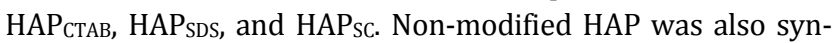

thesized using the same procedure for comparison studies and denoted as HAP BLANK.

\subsection{Characterization of catalysts}

The crystallinity of the catalysts was established and identified by X-ray diffraction (XRD, Rigaku D/max- $\gamma \mathrm{b}$ X-ray diffractometer, Japan) using $\mathrm{Cu} K_{\alpha}$ radiation in the $2 \theta$ range of $10^{\circ}-80^{\circ}$ at room temperature. Fourier transform infrared spectroscopy (FTIR) was carried out on specimens that were prepared into pellets containing the HAP samples and $\mathrm{KBr}$. FTIR spectra were recorded on a Shimadzu IRPrestige-21 spectrophotometer (Japan) in the range of 4000-400 $\mathrm{cm}^{-1}$. A background spectrum of $\mathrm{KBr}$ was subtracted from each sample spectrum. Scanning electron microscopy (SEM) analysis was performed on a JEOL JSM-6360 scanning electron microscope (USA) operating at an acceleration voltage of $20-30 \mathrm{kV} . \mathrm{N}_{2}$ adsorption-desorption measurements were carried out on a Quantachrome Quadrasorb S1 (USA). Prior to analysis, each sample was heated at $200{ }^{\circ} \mathrm{C}$ for $4 \mathrm{~h}$ under vacuum. Surface areas were calculated using the BET method. The pore size was calculated using the BJH model. Thermogravimetry/derivative thermogravimetry analysis (TG/DTG) was performed on a WCT-1C thermobalance (Beijing) in thetemperature range of $20-900{ }^{\circ} \mathrm{C}$.

\subsection{Catalytic activity tests}

HCHO oxidation activity tests were carried out in a fixed-bed flow reactor under atmospheric pressure. Typically, $0.2 \mathrm{~g}$ catalyst was loaded in a quartz tube reactor for activity test. The catalyst was calcined at $400{ }^{\circ} \mathrm{C}$ for $1 \mathrm{~h}$ in an $\mathrm{O}_{2} / \mathrm{Ar}$ flow before the reaction. During the reaction, gaseous HCHO was generated by flowing He over trioxymethylene (99.5\%, Acros Organics) in an incubator placed in an ice-water mixture. The feeding stream consisted of $500 \mathrm{ppm} \mathrm{HCHO}, 20 \mathrm{vol} \% \mathrm{O}_{2}$, and balanced $\mathrm{He}$; the total flow rate throughout the reactor was maintained at $30 \mathrm{~mL} / \mathrm{min}$ by a mass flow meter. The effluents from the reactor were analyzed by an online gas chromatograph (GC 7890II, Techcomp, China) equipped with a flame ionization detector (FID). To determine the exact concentration of produced $\mathrm{CO}_{2}$, a nickel catalyst converter was positioned in front of the FID to convert $\mathrm{CO}_{2}$ quantitatively into methane in the presence of hydrogen. Generally, the reaction data were collected until reaction balance was reached. No other carbon-containing compounds except for $\mathrm{CO}_{2}$ in the products were detected for all the tested catalysts. Thus, the HCHO conversion was calculated as: $\mathrm{HCHO}$ conversion $=\left[\mathrm{CO}_{2}\right] /\left[\mathrm{CO}_{2}\right]^{*} \times 100 \%$, where $\left[\mathrm{CO}_{2}\right]^{*}$ and $\left[\mathrm{CO}_{2}\right]$ represent respective concentrations of $\mathrm{CO}_{2}$ detected in the effluent when $\mathrm{HCHO}$ is completely oxidized and at a given reaction temperature, respectively.

\section{Results and discussion}

\subsection{Catalytic activity for HCHO oxidation}

The catalytic activities of HAP BLANK and modified HAP sam- 


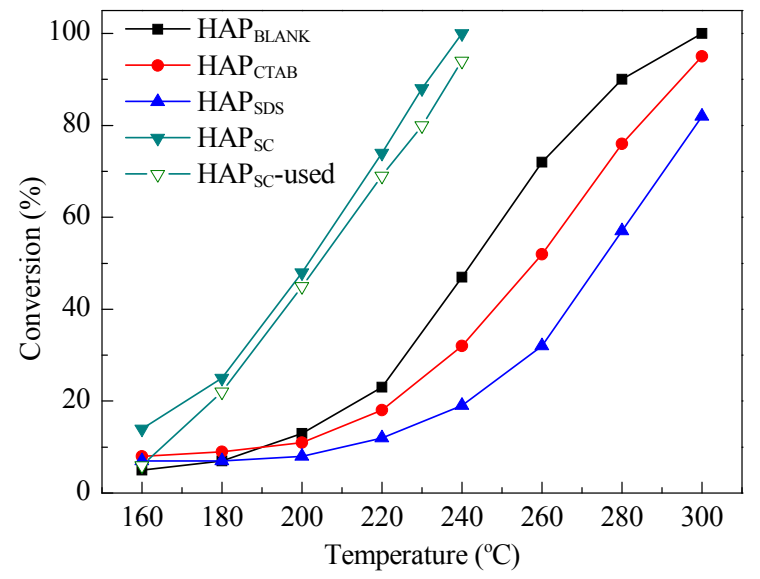

Fig. 1. HCHO conversion over HAP $\mathrm{BLANK}_{\text {and }}$ andified HAP samples.

ples towards the oxidation of $\mathrm{HCHO}$ are shown in Fig. 1. As noted, the HAPsc sample displayed the best activity with $100 \%$ $\mathrm{HCHO}$ conversion at $240{ }^{\circ} \mathrm{C}$. In contrast, the remaining three samples exhibited HCHO conversion levels of less than $50 \%$ at the same temperature. Moreover, the addition of either CTAB or SDS during sample preparation resulted in catalysts with lower activities when compared with that of the blank sample. Complete conversion was not observed even at $300{ }^{\circ} \mathrm{C}$ for the $\mathrm{HAP}_{\text {CTAB }}$ and HAPSDS samples. Further activity tests were performed on the used HAPsc catalyst to determine the stability of the sample. The results are also shown in Fig. 1. As observed, the activity of HAPsc-used only decreased very slightly when compared with that of HAPsc-fresh, indicating the good stability of the catalyst.

\subsection{Catalyst characterization}

\subsubsection{XRD analysis}

XRD patterns of the prepared HAP samples are shown in Fig. 2. Characteristic peaks of HAP (PDF No. 09-0432) [31] were clearly observed in all patterns, indicating successful formation of the HAP structure. Besides the good agreement with the standard HAP pattern, no impurities or distinct differences were observed in the XRD patterns, thereby implying

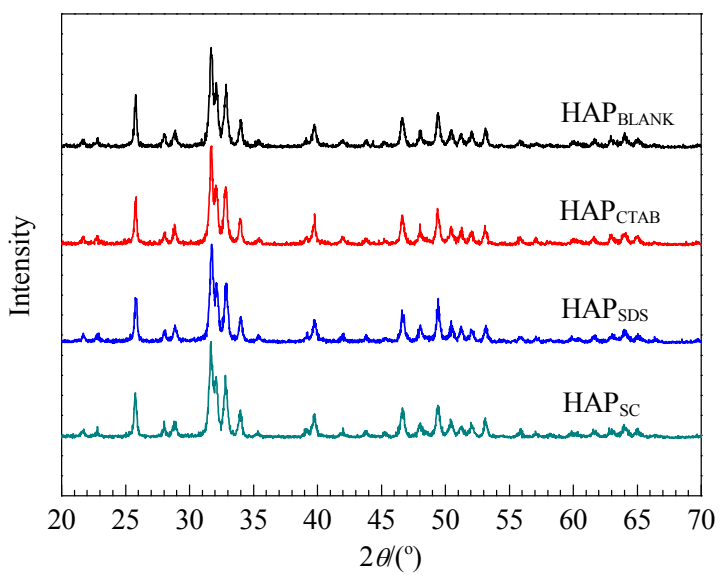

Fig. 2. XRD patterns of HAP $\mathrm{BLANK}_{\text {and }}$ and modified HAP samples.

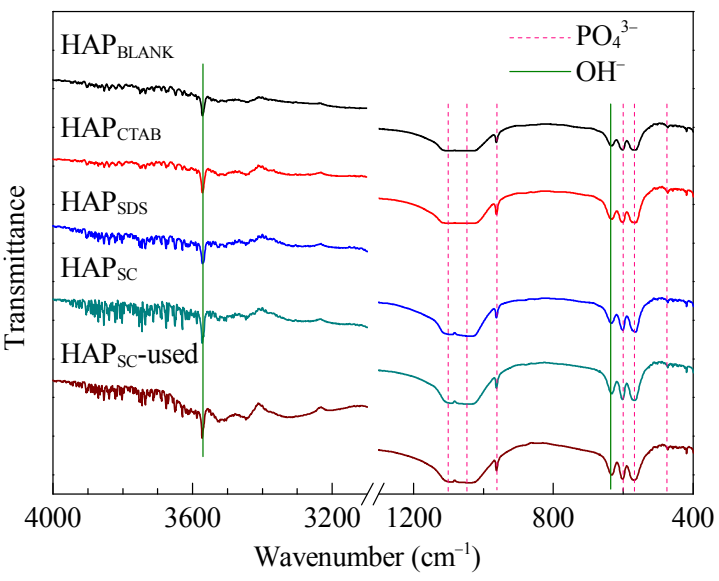

Fig. 3. FTIR spectra of HAP BLANK and modified HAP samples.

that the addition of different organic molecules does not instigate any differences in the crystallinity for samples calcined at the same temperature. Moreover, the good agreement of the XRD patterns of the samples (calcined at $700{ }^{\circ} \mathrm{C}$ ) with characteristic HAP peaks reflects the good thermal stability of the catalysts.

\subsubsection{FTIR spectroscopy}

Figure 3 presents the FTIR spectra of the HAP samples. No organic modifier remained on the surface of HAP after calcination at $700{ }^{\circ} \mathrm{C}$. The presence of $\mathrm{PO}_{4}$ and $\mathrm{OH}$ functional groups was confirmed by various characteristic bands in the FTIR spectra. The peaks at around 1035 and $1091 \mathrm{~cm}^{-1}$ were assigned to asymmetrical stretching modes of $\mathrm{PO}_{4}$ groups, the asymmetrical bending modes of which were detected at around 565 and $602 \mathrm{~cm}^{-1}$ [32]. The symmetrical stretching vibrations of $\mathrm{PO}_{4}$ groups were reflected by bands at around 470 and 962 $\mathrm{cm}^{-1}$ [32]. The peaks observed at 631 and $3580 \mathrm{~cm}^{-1}$ were attributed to the bending and stretching modes of $\mathrm{OH}$ groups in the hydroxyapatite structure, respectively [33]. Although no residual modifiers were detected in the obtained samples, the peak at $3580 \mathrm{~cm}^{-1}$ that corresponds to $\mathrm{OH}$ shows distinct different intensities among the samples. Because the intensity of the peaks is influenced by the amount of samples tested, the $\mathrm{OH}$ content of the samples cannot be directly determined by the intensity of the $\mathrm{OH}$ characteristic peaks. Therefore, the relative peak intensity of the $\mathrm{OH}$ groups to the $\mathrm{PO}_{4}$ groups was used to estimate the $\mathrm{OH}$ content in each sample. The calculated areas of the peak at $3580 \mathrm{~cm}^{-1}$ that was assigned to the stretching mode of $\mathrm{OH}$ groups and the peak at $962 \mathrm{~cm}^{-1}$ that was ascribed to the stretching mode of $\mathrm{PO}_{4}$ groups are shown in Table 1; $\mathrm{OH} / \mathrm{PO}_{4}$ ratios were also calculated based on the calculated areas. HAPsc featured higher $\mathrm{OH} / \mathrm{PO}_{4}$ ratios, indicating that higher amounts of $\mathrm{OH}$ groups were formed on the surface of HAP after modification with SC. It has been proposed that $\mathrm{OH}$ groups play an important role in the adsorption/activation of HCHO [24]. Therefore, the high content of $\mathrm{OH}$ groups in HAPsc was responsible for its significantly improved activity.

The FTIR spectrum of HAPsc-used is also shown in Fig. 3. As observed, the shape of the spectrum of HAPsc-used was not 
Table 1

$\mathrm{OH}$ and $\mathrm{PO}_{4}$ peak areas of different samples detected by FTIR and associated relative $\mathrm{OH} / \mathrm{PO}_{4}$ ratios.

\begin{tabular}{lccc}
\hline Sample & $\begin{array}{c}\text { OH peak area } \\
\left(3580 \mathrm{~cm}^{-1}\right)\end{array}$ & $\begin{array}{c}\mathrm{PO}_{4} \text { peak area } \\
\left(962 \mathrm{~cm}^{-1}\right)\end{array}$ & $\mathrm{OH} / \mathrm{PO}_{4}$ \\
\hline HAP $_{\text {BLANK }}$ & 466 & 198 & 2.35 \\
HAP $_{\text {CTAB }}$ & 617 & 273 & 2.26 \\
HAP $_{\text {SDS }}$ & 580 & 215 & 2.69 \\
HAP $_{S C}$ & 828 & 220 & 3.76 \\
HAP $_{\text {SC-used }}$ & 637 & 175 & 3.64 \\
\hline
\end{tabular}

distinctively different from that of fresh $\mathrm{HAP}_{\mathrm{Sc}}$, further indicating the good stability of the sample. Moreover, the intensity of the $\mathrm{OH}$ groups did not change considerably. For better comparison, the same calculation was adopted to evaluate the $\mathrm{OH}$ content in the two samples (Table 1). Based on the calculated results, the $\mathrm{OH} / \mathrm{PO}_{4}$ ratio only decreased slightly from 3.76 to 3.64. Therefore, the content of the $\mathrm{OH}$ groups can be considered to be stable before and after the reaction, thereby explaining the similarity in the activities of fresh HAPsc and used HAPsc.

\subsubsection{SEM and BET analyses}

The SEM images of the four samples (Fig. 4) display the features and structures of the HAP samples. HAPBLANK and HAPsC possessed a uniform sheet stacking structure with a fluffy surface. The addition of sodium citrate during the synthesis process did not change the integrity or uniformity of HAP structure. In contrast, the addition of CTAB (НАР (HAPSDS) destroyed the uniformity of the samples and featured a relatively compact surface.

Differences in the structure can be evaluated from the $\mathrm{N}_{2}$ adsorption-desorption studies. As shown in Fig. 5(a), all HAP samples featured a type IV adsorption-desorption isotherm with an H3 hysteresis loop according to the IUPAC classification $[29,32]$. The H3 hysteresis loop indicates the presence of a

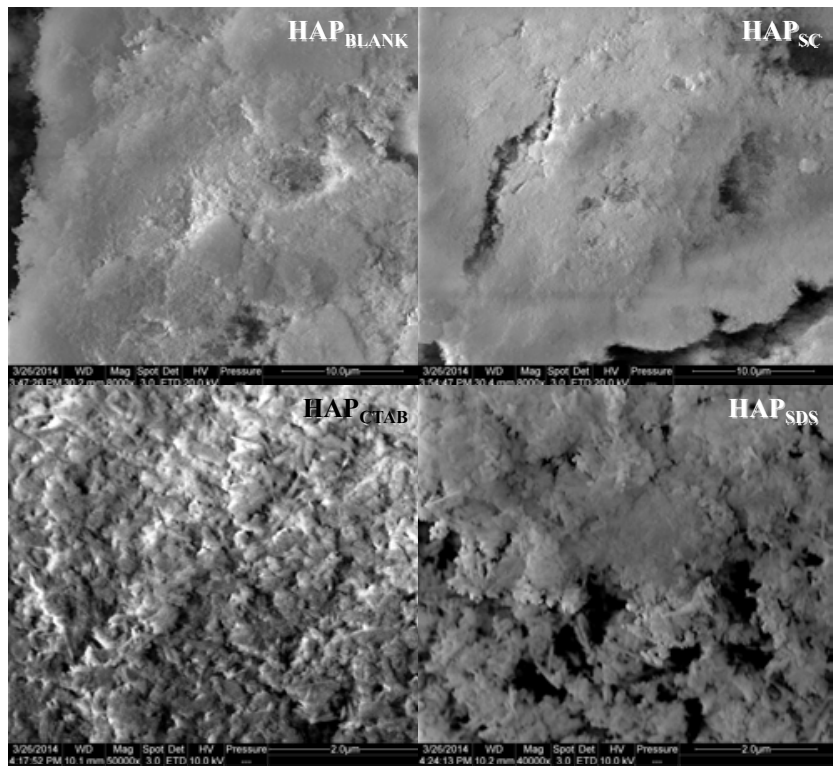

Fig. 4. SEM images of HAP BLANK and modified HAP samples.
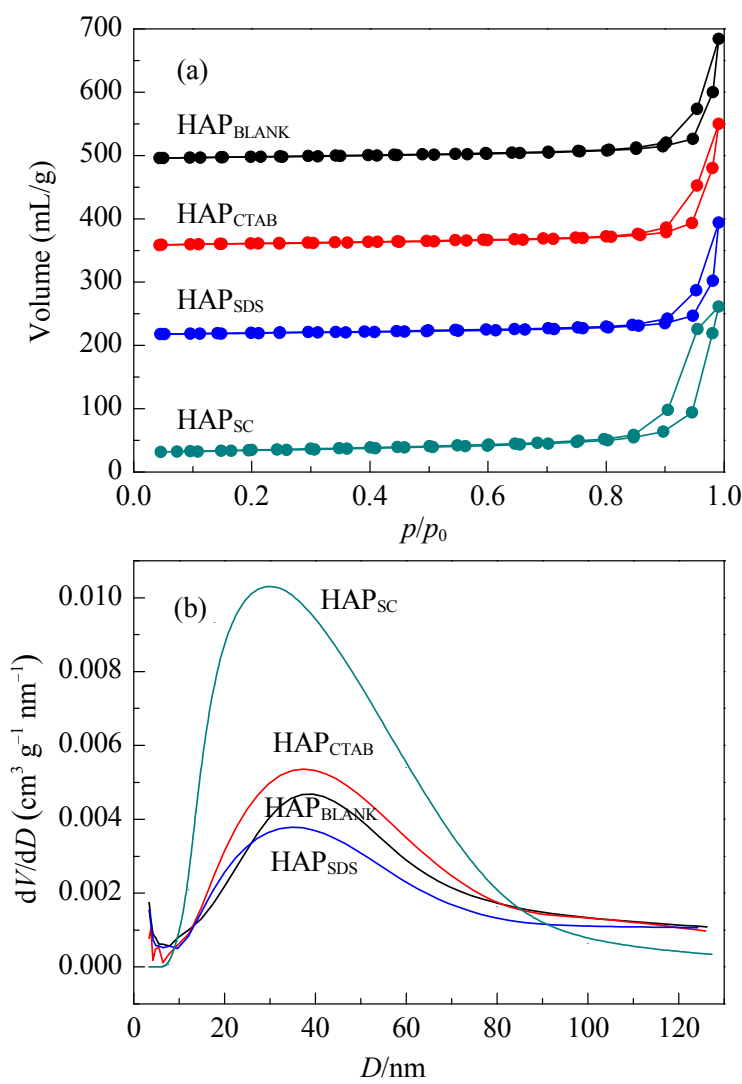

Fig. 5. $\mathrm{N}_{2}$ adsorption-desorption isotherms (a) and pore size distribution (b) of HAP BLANK and modified HAP samples.

sheet stacking structure in the samples, which is in accordance with the SEM analysis. In comparison with the isotherms of the three other samples, HAPSC featured a different desorption branch at the higher $p / p_{0}$ values that is indicative of the presence of relatively uniform and small pores, owing to the existing resistance during the desorption process. This trend can be observed in Fig. 5(b) that shows the pore size distribution of all four HAP samples; accordingly, the pore size distribution of

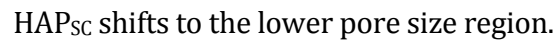

The textural properties, including the specific surface area, pore volume, and average pore diameter, of the studied samples are listed in Table 2. The specific surface areas of the four samples were in the range of $26-40 \mathrm{~m}^{2} / \mathrm{g}$. The average pore size was around $40 \mathrm{~nm}$. As observed, the sample modified with SC, which presented the best catalytic activity, possessed the highest specific surface area $\left(40.36 \mathrm{~m}^{2} / \mathrm{g}\right)$ and pore volume $\left(0.3692 \mathrm{~m}^{3} / \mathrm{g}\right)$, and the smallest average pore diameter $(36.58$ $\mathrm{nm})$. In contrast, the SDS-modified HAP sample showed oppo-

Table 2

Textural properties of samples analyzed by $\mathrm{N}_{2}$ adsorption-desorption method.

\begin{tabular}{lccc}
\hline Sample & $\begin{array}{c}\text { BET surface area } \\
\left(\mathrm{m}^{2} / \mathrm{g}\right)\end{array}$ & $\begin{array}{c}\text { Pore volume } \\
\left(\mathrm{m}^{3} / \mathrm{g}\right)\end{array}$ & $\begin{array}{c}\text { Average diameter } \\
(\mathrm{nm})\end{array}$ \\
\hline HAP $_{\text {BLANK }}$ & 26.42 & 0.3004 & 45.48 \\
HAP $_{\text {CTAB }}$ & 27.52 & 0.3049 & 44.32 \\
HAP $_{\text {SDS }}$ & 23.13 & 0.2801 & 48.44 \\
HAPSC & 40.36 & 0.3692 & 36.58 \\
\hline
\end{tabular}


site trends. The higher specific surface area and pore channel of $\mathrm{HAP}_{\mathrm{SC}}$ provide additional sites for HCHO adsorption, whereas the smaller pores contribute to longer retention times and favor reactions between $\mathrm{HCHO}$ and oxygen on HAP.

\subsection{Effect of organic modifiers and structure-performance relationship}

Based on the characterization results discussed above, it can be seen that the addition of organic modifiers did not cause considerable differences in the crystallinity of the resulting samples, and no organic modifiers were retained in the obtained HAP samples. Thus, in the present work, it can be deduced that neither the crystallinity nor the presence of the new groups introduced into HAP contributes to the improved performance of HAPS. In contrast, the specific surface area and pore structure, which usually influence adsorption and mass transfer during the reaction, are significantly influenced by the addition of various organic modifiers.

The FTIR spectrum of non-calcined HAPSC is shown in Fig. 6; characteristic peaks assigned to the stretching vibrations of carboxyl and $\mathrm{C}-\mathrm{O}$ groups were detected [30], indicating the presence of citrate on the SC-modified HAP sample. Those peaks were not observed in the calcined HAPsc sample, thereby suggesting that the citrate could be completely decomposed during calcination. The decomposition of citrate could also be confirmed from the thermogravimetry/derivative thermogravimetry (TG/DTG) curve of HAPsc (non-calcined) shown in Fig. 7. The TG curve of the HAP sample modified with SC (before calcination) showed a single and continuous weight loss. However, according to the DTG curve, which reflects the rates of weight loss, three main weight loss stages under $600{ }^{\circ} \mathrm{C}$ were observed. The first stage $\left(<150^{\circ} \mathrm{C}\right)$ corresponds to evaporation of water [34], which accounts for a weight loss of about $2 \%$. The second and third weight loss stages, observed at the higher temperatures $\left(200-600^{\circ} \mathrm{C}\right)$ correspond to the decomposition of the anhydrous citrate and the produced intermediate complex [35]. The total weight loss $\left(<600^{\circ} \mathrm{C}\right)$ is about $5.7 \%$, which is slightly higher than the amount of SC added to the solution during the synthesis procedure (i.e., $5 \%$ ), and can be related to the water loss. Further weight loss above $600{ }^{\circ} \mathrm{C}$ may be due to carbon loss from the system [34]. The decomposition of sodium citrate attached to HAP can generate structural vacancies and

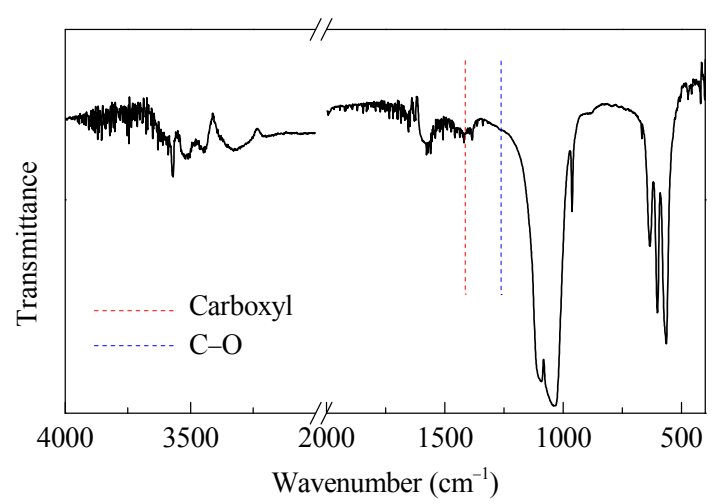

Fig. 6. FTIR spectrum of non-calcined HAPsc.

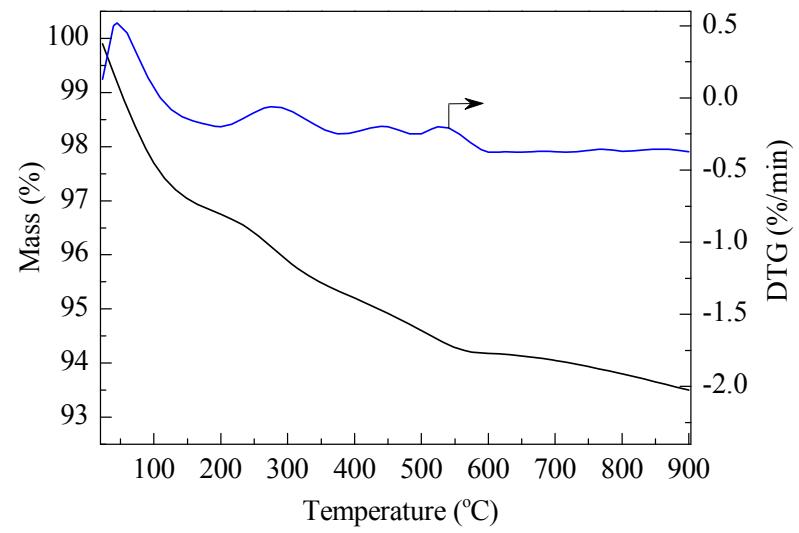

Fig. 7. TG/DTG curves of the HAPsc sample before calcination.

contribute to the higher specific surface area and pore volume observed [29]. In addition, the minor weight loss (600-900 $\left.{ }^{\circ} \mathrm{C}\right)$ partly reflects the good thermal stability of the material.

Based on the characterization results, HAPSC possessed larger specific surface area and pore volume owing to the decomposition of SC during calcination. These features contributed to the improved activity of the resulting catalyst by facilitating the adsorption process during the reaction. Moreover, the smaller pores of HAPSC led to longer retention times of the HCHO molecules in the pores. Also, modification of HAP with SC resulted in increased amounts of hydroxyl groups in the resulting $\mathrm{HAP}_{\mathrm{SC}}$; it has been proposed that hydroxyl groups are responsible for the HCHO catalytic oxidation on HAP [24]. Therefore, better adsorption properties, longer retention times, and larger contents of $\mathrm{OH}$ groups all lead to better interactions between the reaction gas and active sites of the catalysts, consequently resulting in significantly enhanced performance of

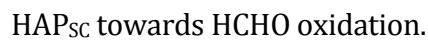

CTAB and SDS are typically used to regulate the morphology of HAP; pores are generated upon elimination of the modifiers $[25,27,28,36]$. Upon addition of template CTAB, the positive head of CTAB is assembled onto HAP; a large amount of $\mathrm{NH}_{4}{ }^{+}$ ions are present in the precipitated HAP. During calcination, the organic CTAB templating structures and ammonium salt are decomposed, leading to the generation of pores in the HA skeleton [28]. However, the size of the pores induced by the decomposition of the organic CTAB templating structure is different from that of pores generated by removal of the ammonium salt, thereby explaining the non-uniformity of the resulting sample structure [28]. A similar decomposition process of the sulfate groups was also observed for SDS [27]. It is known from the chemical structure of CTAB, SDS, and SC that at least two types of gases were released during calcination of $\mathrm{HAP}$ СТАВ $\left(\mathrm{CO}_{2}, \mathrm{NH}_{3}\right)$ and HAPSDS $\left(\mathrm{CO}_{2}, \mathrm{SO}_{2}\right)$. This caused the poor uniformity of the pores in the samples, as reflected by the wide pore size distributions and the non-uniform structures shown in the SEM images. Moreover, the presence of the longer alkyl chain lengths of CTAB and SDS also instigated the formation of larger pores $[37,38]$. Therefore, the larger pores and poor uniformity of the structures of $\mathrm{HAP}_{\mathrm{CTAB}}$ and HAPSDS were due to the structure and composition of CTAB and SDS, as well as the de- 
composition properties of the surfactant. In contrast, $\mathrm{CO}_{2}$ was mostly generated during the calcination of $\mathrm{HAP}_{\mathrm{SC}}$, and the smaller SC molecules led to the formation of smaller pores.

\section{Conclusions}

Modification of HAP with different organic modifiers (CTAB, SDS, and SC) resulted in differences in the specific surface area and pore structure of the final modified HAP samples. Modification with SC significantly improved the activity of HAP towards HCHO oxidation, with complete conversion achieved at $240{ }^{\circ} \mathrm{C}$. HAPsc featured larger specific surface area and pore volume that enhanced the adsorption capacity for $\mathrm{HCHO}$ whereas the smaller pores afforded sufficient time for interaction between the catalyst and reaction gas. Besides the structural differences that influenced adsorption and mass transfer, the content of hydroxyl groups that is responsible for $\mathrm{HCHO}$ oxidation was higher in the SC-modified HAP sample. Better adsorption properties, longer retention times, and larger contents of $\mathrm{OH}$ groups of HAPSC all lead to better interaction between the reaction gas and active sites of the catalysts, and subsequent significantly enhanced performance of HAPSC towards HCHO oxidation.

\section{References}

[1] Pei J J, Zhang J S. HVAC\&R Res, 2011, 17: 476

[2] Yu C, Crump D. Build Environ, 1998, 33: 357

[3] Jia M L, Shen Y N, Li C Y, Bao Z, Sheng S S. Catal Lett, 2005, 99: 235

[4] Zhang C B, He H, Tanaka K. Catal Commun, 2005, 6: 211

[5] Peng J X, Wang S D. Appl Catal B, 2007, 73: 282

[6] Qu Z P, Shen S J, Chen D, Wang Y. J Mol Catal A, 2012, 356: 171

[7] Tang X F, Li Y G, Huang X M, Xu Y D, Zhu H Q, Wang J G, Shen W J. Appl Catal B, 2006, 62: 265

[8] Liu X S, Lu J Q, Qian K, Huang W X, Luo M F. J Rare Earths, 2009, 27: 418
[9] Wang R H, Li J H. Catal Lett, 2009, 131: 500

[10] Tang X F, Chen J L, Huang X M, Xu Y D, Shen W J. Appl Catal B, 2008, 81: 115

[11] Li C Y, Shen Y N, Jia M L, Sheng S S, Adebajo M O, Zhu H Y. Catal Commun, 2008, 9: 355

[12] Ma C Y, Wang D H, Xue W J, Dou B J, Wang H L, Hao Z P. Environ Sci Technol, 2011, 45: 3628

[13] Tang X F, Chen J L, Li Y G, Li Y, Xu Y D, Shen W J. Chem Eng J, 2006, 118: 119

[14] Zhang C B, He H, Tanaka K. Appl Catal B, 2006, 65: 37

[15] Sierra P, Chakrabarti S, Tounkara R, Loranger S, Kennedy G, Zayed J. Environ Res, 1998, 79: 94

[16] Reaney S H, Kwik-Uribe C L, Smith D R. Chem Res Toxicol, 2002, 15: 1119

[17] Zhao D Z, Ding T Y, Li X S, Liu J L, Shi C, Zhu A M. Chin J Catal (赵德 志, 丁大英, 李小松, 刘景林, 石川, 朱爱民. 催化学报), 2012, 33: 396

[18] Ma L, Wang D S, Li J H, Bai B Y, Fu L X, Li Y D. Appl Catal B, 2014, 148-149: 36

[19] Bai B Y, Arandiyan H, Li J H. Appl Catal B, 2013, 142-143: 677

[20] Wei R C, Chen H L, Zhang X M, Suo J S. Chin J Catal (魏日出, 陈洪林, 张小明, 索继栓. 催化学报), 2013, 34: 1945

[21] Park S M, Jeon S W, Kim S H. Catal Lett, 2014, 144: 756

[22] An N H, Wu P, Li S Y, Jia M J, Zhang W X. Appl Surf Sci, 2013, 285: 805

[23] Low H R, Avdeev M, Ramesh K, White T J. Adv Mater, 2012, 24 4175

[24] Xu J, White T, Li P, He C H, Han Y F. J Am Chem Soc, 2010, 132: 13172

[25] Gopi D, Indira J, Nithiya S, Kavitha L, Kamachi Mudali U, Kanimozhi K. Bull Mater Sci, 2013, 36: 799

[26] Yan H, Hao L J, Zhao N R, Huang M J, Du C, Wang Y J. Mater Chem Phys, 2013, 141: 488

[27] Yan L, Li Y D, Deng Z X, Zhuang J, Sun X M. Int J Inorg Mater, 2001, 3: 633

[28] Wang H L, Zhai L F, Li Y H, Shi T J. Mater Res Bull, 2008, 43: 1607

[29] Dominguez M I, Romero-Sarria F, Centeno M A, Odriozola J A. Appl Catal B, 2009, 87: 245

[30] Wang A L, Liu D, Yin H B, Wu H X, Wada Y, Ren M, Jiang T S, Cheng

\section{Graphical Abstract}

Chin. J. Catal., 2014, 35: 1927-1936 doi: 10.1016/S1872-2067(14)60129-7

\section{Formaldehyde catalytic oxidation over hydroxyapatite modified with various organic modifiers}

Yahui Sun, Zhenping Qu*, Dan Chen, Hui Wang, Fan Zhang, Qiang Fu Dalian University of Technology; Dalian Institute of Chemical Physics, Chinese Academy of Sciences
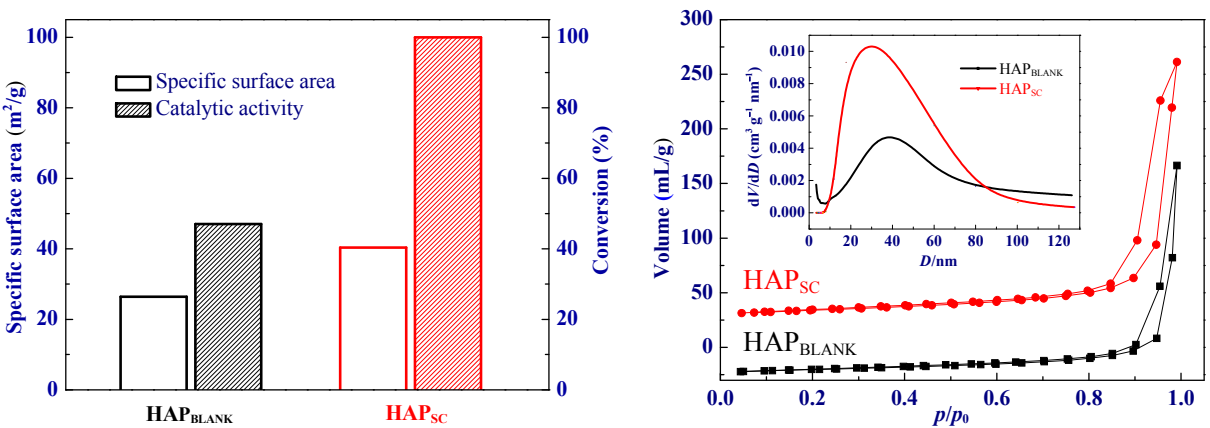

Better adsorption properties, longer retention times, and larger contents of $\mathrm{OH}$ groups of hydroxyapatite modified with sodium citrate (SC) (HAPsc) lead to better interaction between the reaction gas and active sites and higher activity towards HCHO oxidation. 
X N, Xu Y Q. Mater Sci Eng C, 2007, 27: 865

[31] Diaz A, Lopez T, Manjarrez J, Basaldella E, Martinez-Blanes J M, Odriozola J A. Acta Biomater, 2006, 2: 173

[32] Tounsi H, Djemal S, Petitto C, Delahay G. Appl Catal B, 2011, 107: 158

[33] Boukha Z, Kacimi M, Ziyad M, Ensuque A, Bozon-Verduraz F. J Mol Catal A, 2007, 270: 205
[34] Shum H C, Bandyopadhyay A, Bose S, Weitz D A. Chem Mater, 2009, 21: 5548

[35] Gajbhiye N S, Balaji G. Thermochim Acta, 2002, 385: 143

[36] Wu X D, Song X F, Li D S, Liu J G, Zhang P B, Chen X S. J Bionic Eng, 2012, 9: 224

[37] Chen D, Qu Z P, Sun Y H, Wang Y. Colloid Surf A, 2014, 441: 433

[38] Huo Q S, Margolese D I, Stucky G D. Chem Mater, 1996, 8: 1147

\section{不同有机分子改性羟基磷灰石用于甲醛催化氧化 孙亚会 ${ }^{\mathrm{a}}$, 曲振平 ${ }^{\mathrm{a},}{ }^{*}$, 陈 丹 , $^{\mathrm{a}}$ 王 辉 ${ }^{\mathrm{a}}$, 张 帆 ${ }^{\mathrm{b}}$, 傅 强 ${ }^{\mathrm{b}}$ a 大连理工大学环境学院工业生态与环境工程教育部重点实验室, 辽宁大连 116024 \\ $\mathrm{b}$ 中国科学院大连化学物理研究所催化基础国家重点实验室, 辽宁大连 116023}

摘要: 分别采用十六烷基三甲基溴化铵(CTAB)、十二烷基硫酸钠(SDS)及柠檬酸钠(SC)对羟基磷灰石(HAP)进行了有机改性. 柠 檬酸钠改性的羟基磷灰石对甲醛催化氧化表现出最好的催化活性, 在 $240^{\circ} \mathrm{C}$ 实现了甲醛完全转化. 通过X射线衍射、红外光谱、 $\mathrm{N}_{2}$ 吸附-脱附、扫描电镜和热重/差重等手段对HAP结构进行了表征. 结果表明, SC改性使得HAP比表面积和孔体积增加, 孔径减 小, 更有利于吸附及传质, 从而提高了其活性. 此外, SC改性的HAP中羟基含量更多, 更有利于甲醛与羟基之间发生相互作用, 这 是该样品活性提高的另一个原因.

关键词: 羊基磷灰石改性; 柠檬酸钠; 比表面积; 羊基; 甲䤊催化氧化

收稿日期: 2014-04-13. 接受日期: 2014-04-28. 出版日期: 2014-12-20.

*通讯联系人. 电话: 15542663636; 传真: (0411)84708083; 电子信箱：quzhenping@dlut.edu.cn 基金来源：国家自然科学基金(21377016); 中央高校基本科研业务费专项资金(DUT13LK27); 长江学者和创新团队发展计划 (IRT 13R05).

本文的英文电子版由Elsevier出版社在ScienceDirect上出版(http://www.sciencedirect.com/science/journal/18722067).

\section{1. 前言}

作为一种最常见的挥发性有机化合物, 甲醛因其所 具有的高毒性而引起了人们越来越多的关注, 即使是低 剂量的甲醛, 长期接触也对人体具有潜在危害. 因此, 甲 醛的消除是亟待解决的问题之一 ${ }^{[1,2]}$. 甲醛消除可采用 多种技术, 包括吸附法、等离子体技术、生物过滤法以 及催化氧化等 ${ }^{[1]}$. 其中, 催化氧化因简便高效且不存在 二次污染等优点而具有良好的发展前景. 该过程常用的 催化剂为贵金属催化剂 $(\mathrm{Pt}, \mathrm{Au}, \mathrm{Pd} \text { 和 } \mathrm{Ag} \text { 等 })^{[3-6]}$ 和过渡金 属氧化物 $\left(\mathrm{MnO}_{x}\right.$ 和 $\mathrm{CeO}_{2}$ 等)两类 ${ }^{[7-9]}$. 其中, 过渡金属氧 化物也常用作贵金属催化剂的载体 ${ }^{[10-13]}$. 贵金属催化剂 在甲醛催化氧化反应中通常表现出较好的催化活性, 甲 醛完全转化温度一般在 $100{ }^{\circ} \mathrm{C}$ 左右或更低 ${ }^{[5,14]}$. 然而, 贵 金属昂贵的价格使得这类催化剂难以得到广泛的实际 应用. 过渡金属氧化物用于甲醛催化氧化催化剂时, 在 大部分情况下甲醛的完全转化温度在 $100^{\circ} \mathrm{C}$ 以上, 有时 甚至超过 $200{ }^{\circ} \mathrm{C}^{[7,9,13]}$; 此外, 有些过渡金属氧化物(如 $\mathrm{MnO}_{x}$ ) 具有毒性 ${ }^{[15,16]}$, 也不利于广泛应用. 近年来, 随着 研究的进展, 甲醛氧化所用贵金属催化剂及过渡金属氧 化物催化剂如 $\mathrm{MnO}_{x}, \mathrm{Ag} / \mathrm{CeO}_{2}, \mathrm{Co}_{3} \mathrm{O}_{4}$ 和 $\mathrm{Pt} / \mathrm{CeO}_{2}$ 等 ${ }^{[17-22]}$ 的性能得到了提高, 但它们的缺点仍未得到解决. 因此,
对于甲醛催化氧化, 需要开发经济且安全无毒的新型催 化剂来克服贵金属催化剂及过渡金属氧化物的固有缺 陷.

羟基磷灰石(HAP)是骨骼与牙齿的主要天然无机成 分, 安全无毒, 作为生物活性材料在生物医用材料领域 有着广泛的应用 ${ }^{[23]}$. 此外, 作为一种来源广泛的非贵金 属材料, HAP价格低廉. 2010年, Xu等 ${ }^{[24]}$ 研究表明, HAP 对甲醛催化氧化表现出了一定的活性, 是一种具有发展 前景的新型非贵金属材料, 其位于HAP六边形孔道内的 羟基可能是甲醛催化氧化反应的活性位.

迄今, HAP用于甲醛催化氧化的研究还十分少见. 然而, 由于HAP是一种安全无毒的非贵金属材料, 且单 独用于甲醛催化氧化表现出了良好活性, 因此将它作为 催化材料进行较为详细的研究具有重要意义. 众所周 知, 催化剂催化性能与其结构密切相关. 研究发现, 催化 氧化过程中甲醛的吸附及其与催化剂之间的相互作用 都会影响催化剂的活性 ${ }^{[1]}$, 较大的吸附容量及较充分的 相互作用对催化剂活性的提高具有重要作用. 另外, 采 用有机改性剂可对纳米金属材料及无机材料的形貌、粒 径及结构等进行调控 ${ }^{[25]}$. 因此, 本文在HAP合成过程中 加入常用有机改性剂(十六烷基三甲基溴化铵(CTAB)、 十二烷基硫酸钠(SDS)及柠檬酸钠(SC))对HAP的结构进 
行改性, 并通过有机改性剂高温下的分解在HAP结构中 产生更多缺陷和空穴 ${ }^{[26-30]}$, 同时对催化剂进行多种表征 及活性测试, 并关联多种实验结果得出该类催化剂的构 效关系.

\section{2. 实验部分}

\section{1. 催化剂制备}

采用液相沉淀-水热法制备HAP样品粉末, 制备过 程所用 $\mathrm{HAP}$ 前驱物为 $\left(\mathrm{NH}_{4}\right)_{2} \mathrm{HPO}_{4}$ (分析纯, 天津市科密 欧化学试剂有限公司)和 $\mathrm{Ca}\left(\mathrm{NO}_{3}\right)_{2} \cdot 4 \mathrm{H}_{2} \mathrm{O}$ (分析纯, 天津市 大茂化学试剂厂), 沉淀过程中的 $\mathrm{pH}$ 值采用氨水 $(35 \%$, 分 析纯, 国药集团化学试剂有限公司)调节. 将 $4.72 \mathrm{~g}$ $\mathrm{Ca}\left(\mathrm{NO}_{3}\right)_{2} \cdot 4 \mathrm{H}_{2} \mathrm{O}$ 及 $0.1 \mathrm{~g}$ 有机改性剂(CTAB (分析纯, 国药 集团化学试剂有限公司), SDS (分析纯, 天津市科密欧化 学试剂有限公司)或 $\mathrm{SC}$ (分析纯, 上海化学试剂厂一厂)) 加入 $100 \mathrm{~mL}$ 去离子水中搅拌使其充分溶解, 得到 0.2 $\mathrm{mol} / \mathrm{L} \mathrm{Ca}\left(\mathrm{NO}_{3}\right)_{2}$ 溶液, 其中所含有机改性剂的质量是 $\mathrm{HAP}$ 理论生成量的 $5 \%$. 将含有有机改性剂的 $\mathrm{Ca}\left(\mathrm{NO}_{3}\right)_{2}$ 溶液置于 $40{ }^{\circ} \mathrm{C}$ 水浴锅中摚拌. 称取 $1.58 \mathrm{~g}\left(\mathrm{NH}_{4}\right)_{2} \mathrm{HPO}_{4}$ 溶解于 $40 \mathrm{~mL}$ 去离子水中制得 $0.3 \mathrm{~mol} / \mathrm{L}$ 溶液. 搅拌下将 $\left(\mathrm{NH}_{4}\right)_{2} \mathrm{HPO}_{4}$ 滴加到 $\mathrm{Ca}\left(\mathrm{NO}_{3}\right)_{2}$ 溶液中, 将混合物的 $\mathrm{pH}$ 用氨 水调至 10 , 搅拌下反应 $8 \mathrm{~h}$. 将反应所得混合物移入反应 釜中, $100{ }^{\circ} \mathrm{C}$ 保持 $12 \mathrm{~h}$. 将所得混合物多次离心、洗涤后 于 $100{ }^{\circ} \mathrm{C}$ 干燥过夜, $700{ }^{\circ} \mathrm{C}$ 焙烧 $2 \mathrm{~h}$. 所得样品分别标记 为 $\mathrm{HAP}_{\mathrm{CTAB}}, \mathrm{HAP}_{\mathrm{SDS}}$ 和 $\mathrm{HAP}_{\mathrm{SC}}$. 为了对比, 同上制备了未 经有机改性剂改性的样品 $\mathrm{HAP}_{\text {BLANK}}$.

\section{2. 催化剂表征}

催化剂结晶度通过 $X$ 射线衍射 (XRD) 测试得到, $\mathrm{XRD}$ 测试在日本理学 $\mathrm{D} / \mathrm{max}-\gamma \mathrm{b}$ 型 $\mathrm{X}$ 射线衍射仪上进行, 射线源为 $\mathrm{Cu} K_{\alpha}$ ，扫描在室温下进行，扫描范围 $2 \theta=$ $10^{\circ}-80^{\circ}$. 傅里叶变换红外光谱(FTIR)在日本 Shimadzu IR Prestige-21分光光度计上进行, 将样品与 $\mathrm{KBr}$ 混合压 片制备测试样品, 扫描范围 4000-400 $\mathrm{cm}^{-1}, \mathrm{KBr}$ 的背景 光谱从每个样品的光谱中扣除. 扫描电子显微镜(SEM) 观察在美国JEOL JSM-6360扫描电子显微镜上进行, 加 速电压 20-30 kV. $\mathrm{N}_{2}$ 吸脱附测试在美国Quantachrome Quadrasorb S1 型物理吸附仪上进行, 测试前将样品于 $200{ }^{\circ} \mathrm{C}$ 抽真空预处理 $4 \mathrm{~h}$, 样品的比表面积和孔径分布分 别通过 BET 方程和 BJH方程计算得到。热重分析 (TG/DTG)在WCT-1C型热天平(北京)上进行, 温度测试 范围为 $20-900{ }^{\circ} \mathrm{C}$.

\section{3. 催化剂活性测试}

$\mathrm{HCHO}$ 催化氧化活性测试在固定床石英反应器中 进行, 催化剂用量 $0.2 \mathrm{~g}$. 测试前催化剂在 $\mathrm{O}_{2} / \mathrm{Ar}$ 气氛中 $400{ }^{\circ} \mathrm{C}$ 预处理 $1 \mathrm{~h}$. 反应过程中的甲醛是将 $\mathrm{He}$ 气通入装 有三聚甲醛( $99.5 \%$, Acros Organics) 的恒温器并将其上 方的蒸气带出而产生的. 反应气的组成为 $500 \mathrm{ppm}$ $\mathrm{HCHO}-20 \mathrm{vol} \% \mathrm{O}_{2} / \mathrm{He}$. 反应过程中气体总流量通过质 量流量计控制在 $30 \mathrm{~mL} / \mathrm{min}$. 反应器出口气体由气相色 谱仪(Techcomp, GC 7890II) 在线检测, FID检测器. 为准 确检测出口气体中 $\mathrm{CO}_{2}$ 的浓度, 在FID检测器前设置镍 催化剂转换器, 在 $\mathrm{H}_{2}$ 作用下可将 $\mathrm{CO}_{2}$ 定量转换为甲烷. 反应数据在反应达到平衡后开始采集. 除 $\mathrm{CO}_{2}$ 外未检测 到其他含碳副产物, 因此甲醛转化率可通过下式计算: $\mathrm{HCHO}$ conversion $=\left[\mathrm{CO}_{2}\right] /\left[\mathrm{CO}_{2}\right]^{*} \times 100 \%$, 其 中 $\left[\mathrm{CO}_{2}\right]^{*}$ 和 $\left[\mathrm{CO}_{2}\right]$ 分别为甲醛完全转化时和各反应温度下检测到 的 $\mathrm{CO}_{2}$ 浓度.

\section{3. 结果与讨论}

\section{1. 甲醛催化氧化活性}

$\mathrm{HAP}_{\text {BLANK }}$ 及有机改性HAP的甲醛催化氧化活性如 图1所示. 可以看出, SC改性的HAP(HAP $\left.\mathrm{HC}_{\mathrm{SC}}\right)$ 表现出了最 好的催化活性, 在 $240{ }^{\circ} \mathrm{C}$ 实现了甲醛完全转化. 而其他 样品 $240{ }^{\circ} \mathrm{C}$ 时甲醛转化率均在 $50 \%$ 以下. 与 $\mathrm{HAP}_{\mathrm{BLANK}}$ 相 比, $\mathrm{CTAB}$ 与 $\mathrm{SDS}$ 的改性导致 $\mathrm{HAP}$ 活性下降, 在 $300{ }^{\circ} \mathrm{C}$ 时 甲醛仍未达到完全转化. 为了观察催化剂的稳定性, 对 进行过活性测试的 $\mathrm{HAP}_{\mathrm{SC}}$ 样品( $\mathrm{HAP}_{\mathrm{SC}}$-used)再次进行活 性测试(图1), 与 $\mathrm{HAP}_{\mathrm{SC}}$ 相比, $\mathrm{HAP}_{\mathrm{SC}}$-used的活性并未明 显下降, 表明催化剂具有良好的稳定性.

\section{2. 催化剂表征}

\subsubsection{XRD结果}

图2为各催化剂的XRD谱. 由图可见, 各样品均呈 现出明显的HAP特征衍射峰(PDF No. 09-0432) ${ }^{[31]}$, 说明 它们均具有HAP的结构. 同时, 这四个样品中均未观察 到杂峰, 且各谱图未见明显不同, 表明合成过程中有机 改性剂的加入并未引起结晶度的明显变化. 此外, 与 HAP特征衍射峰良好的契合度表明 $700{ }^{\circ} \mathrm{C}$ 高温焙烧并 未破坏HAP的结构, 说明HAP的热稳定性良好.

\subsubsection{FTIR结果}

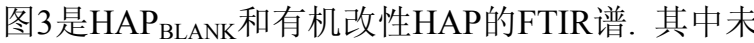
观察到来自改性剂官能团的特征峰, 说明 $700{ }^{\circ} \mathrm{C}$ 焙烧后 有机改性剂未在HAP表面形成残留. 各样品在 1035 和 $1091 \mathrm{~cm}^{-1}$ 处出现归属为 $\mathrm{PO}_{4}$ 基团的非对称伸缩振动峰, 在 565 和 $602 \mathrm{~cm}^{-1}$ 处检测到 $\mathrm{PO}_{4}$ 基团的非对称弯曲振动 
峰 ${ }^{[32]}$. 而 $\mathrm{PO}_{4}$ 基团的对称伸缩振动特征峰出现在 470 和 $962 \mathrm{~cm}^{-1}$ [32]. OH基团的特征峰包括 $631 \mathrm{~cm}^{-1}$ 处的弯曲 振动和 $3580 \mathrm{~cm}^{-1}$ 处的伸缩振动 ${ }^{[33]}$. 尽管FTIR 图谱中未 显示任何有机改性剂官能团的残留, 但样品特征吸收峰 的强度, 尤其是 $3580 \mathrm{~cm}^{-1}$ 处 $\mathrm{OH}$ 的特征吸收峰表现出较 为明显的差异. 由于吸收峰强度受测试样品量的影响, 因此样品中 $\mathrm{OH}$ 的含量并不能通过其特征吸收峰的强度 直接比较. 因此, 需要采用 $\mathrm{OH}$ 对 $\mathrm{PO}_{4}$ 的相对强度来比较 各样品中 $\mathrm{OH}$ 的含量. 通过计算得到的 $\mathrm{OH}\left(3580 \mathrm{~cm}^{-1}\right)$ 和 $\mathrm{PO}_{4}$ 特征吸收峰 $\left(962 \mathrm{~cm}^{-1}\right)$ 的面积如表1所示. 表1还给出 了依据峰面积计算得到的 $\mathrm{OH} / \mathrm{PO}_{4}$. 可以看出, $\mathrm{HAP}_{\mathrm{SC}}$ 样 品具有明显较大的 $\mathrm{OH} / \mathrm{PO}_{4}$ 值, 表明 $\mathrm{SC}$ 改性的HAP样品 中形成了更多的OH. 研究表明 ${ }^{[24]}$, 在甲醛催化氧化过程 中 $\mathrm{OH}$ 对甲醛的吸附与活化具有重要作用. 因此, $\mathrm{HAP}_{\mathrm{SC}}$ 中较高的 $\mathrm{OH}$ 含量可能是其活性大幅提高的原因之一.

从图 3 还可以看出, $\mathrm{HAP}_{\mathrm{SC}}$ 和 $\mathrm{HAP}_{\mathrm{SC}}$-used 样品的 FTIR谱并未表现出明显差异, 同样说明了催化剂在反应 前后较好的稳定性. 同时, $\mathrm{OH}$ 的特征吸收峰强度并未发 生明显改变. 从表1可以看出, 反应后 $\mathrm{HAP}_{\mathrm{SC}}$-used样品的 $\mathrm{OH} / \mathrm{PO}_{4}$ 值从 3.76稍降至3.64. 因此, 可以认为反应前后 样品中 $\mathrm{OH}$ 的含量是稳定的, 这也解释了 $\mathrm{HAP}_{\mathrm{SC}}$ 和 $\mathrm{HAP}_{\mathrm{SC}}$-used活性相近.

\subsubsection{SEM和BET结果}

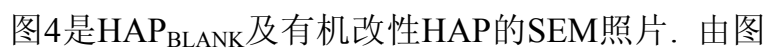
可知, $\mathrm{HAP}_{\mathrm{BLANK}}$ 和 $\mathrm{HAP}_{\mathrm{SC}}$ 为较为均匀的片状堆积结构, 且表面疏松. SC的加入并未破坏HAP样品本身结构的

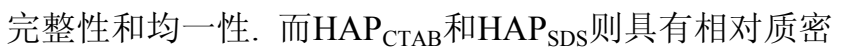
的表面结构, 且HAP的均一性受到破坏.

图 5 为各HAP样品的吸附-脱附等温线和孔径分布 图. 根据IUPAC分类, 所有样品吸脱附等温线均为IV型, 回滞环为 H3 型 ${ }^{[29,32]}$. H3 型回滞环说明样品呈片状粒子 堆积, 这与 SEM结果一致. 与其他三条等温线相比, $\mathrm{HAP}_{\mathrm{SC}}$ 的脱附支在高 $p / p_{0}$ 区域呈现出形状上的差异, 说 明 $\mathrm{N}_{2}$ 在 $\mathrm{HAP}_{\mathrm{SC}}$ 上的脱附过程中遇到了更多的阻力, 进一 步表明 $\mathrm{HAP}_{\mathrm{SC}}$ 具有较小的孔径及较为规则的孔道. 如图 5(b)所示, 四个样品均显示出较宽范围的孔径分布, 其中 以 $\mathrm{HAP}_{\mathrm{SC}}$ 的孔径分布最为集中, 且向较小孔径方向移动.

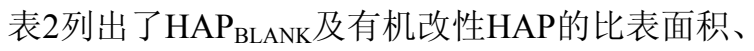
孔体积及孔径. 可见, 四个样品的比表面积在 26-40 $\mathrm{m}^{2} / \mathrm{g}$, 平均孔径在 $40 \mathrm{~nm}$ 左右. 其中 $\mathrm{HAP}_{\mathrm{SC}}$ 具有最大的比 表面积 $\left(40.36 \mathrm{~m}^{2} / \mathrm{g}\right)$ 及孔体积 $\left(0.3692 \mathrm{~m}^{3} / \mathrm{g}\right)$, 而其平均孔 径 $\left(36.58 \mathrm{~nm}\right.$ ) 则明显减小. 与 $\mathrm{HAP}_{\mathrm{BLANK}}$ 相比, $\mathrm{HAP}_{\mathrm{SDS}}$ 样
品的比表面积与孔结构的变化趋势与 $\mathrm{HAP}_{\mathrm{SC}}$ 相反. $\mathrm{HAP}_{\mathrm{SC}}$ 较大的比表面积及孔体积能给甲醛提供更大的吸 附容量, 且较小的孔径加长了反应气的停留时间, 有利 于反应气与催化剂充分接触, 从而有利于 $\mathrm{HAP}_{\mathrm{SC}}$ 活性的 提高.

\section{3. 有机改性剂的影响及催化剂构效关系}

根据上述表征结果可知, 合成过程中有机改性剂的 加入并未导致最终样品结晶度的差异, 且在最终样品中 没有有机改性剂的残留. 由此可推断, 在本实验中, 并非 结晶度的不同或组合到HAP上的来自有机改性剂的新 基团导致了样品间活性的差异. 合成过程中不同有机改 性剂的加入导致比表面积及孔结构较大的改变, 而比表 面积及孔结构通常会影响催化反应过程中的吸附与传 质过程, 从而影响催化剂的活性.

图6是未焙烧 $\mathrm{HAP}_{\mathrm{SC}}$ 的FTIR谱. 在谱图中观察到了 羧基及 $\mathrm{C}-\mathrm{O}$ 的特征伸缩振动吸收峰 ${ }^{[30]}$, 说明在未焙烧 $\mathrm{HAP}_{\mathrm{SC}}$ 样品中 $\mathrm{SC}$ 的存在. 但经 $700{ }^{\circ} \mathrm{C}$ 焙烧后, 这些特征 吸收峰消失, 表明在焙烧过程中 $\mathrm{SC}$ 能完全分解. 同时, $\mathrm{SC}$ 的分解可通过未焙烧 $\mathrm{HAP}_{\mathrm{SC}}$ 的 TG/DTG曲线(图 7)得 到证实. $\mathrm{HAP}_{\mathrm{SC}}$ 的 $\mathrm{TG}$ 曲线表现出了持续的质量损失, 而 从反应样品质量损失速率的DTG曲线来看, 未焙烧的 $\mathrm{HAP}_{\mathrm{SC}}$ 在 $600{ }^{\circ} \mathrm{C}$ 以下有三个质量损失阶段. 第一阶段发 生在 $150{ }^{\circ} \mathrm{C}$ 以下, 来自水的蒸发 ${ }^{[34]}$, 这一阶段的质量损 失为 $2 \%$. 随着温度升高, 在 $200-600{ }^{\circ} \mathrm{C}$ 间出现了第二及 第三次质量损失, 这两阶段分别对应于柠檬酸根及其分 解中间产物的再次分解 ${ }^{[35]}$. $600{ }^{\circ} \mathrm{C}$ 以下的总质量损失为 $5.7 \%$, 比合成过程中加入的 SC的质量 $(5 \% \mathrm{HAP}$ 理论质 量)稍大, 是由于水分损失造成的. 高于 $600{ }^{\circ} \mathrm{C}$ 持续的慢 速质量损失可能是来自系统中的碳损失 ${ }^{[34]}$. 焙烧过程 中 SC的分解能在HAP结构中产生空穴, 从而使其具有较 大的比表面积及孔体积 ${ }^{[29]}$. 此外, 样品加热到 $900{ }^{\circ} \mathrm{C}$ 高 温时的质量损失依然很少, 这也反映出材料较好的热稳 定性.

以上表征结果显示, $\mathrm{HAP}_{\mathrm{SC}}$ 在焙烧过程中发生了 $\mathrm{SC}$ 的分解, 从而导致其较大的比表面积及孔体积, 有利于 反应中的吸附过程, 使得催化剂活性提高. 同时, $\mathrm{HAP}_{\mathrm{SC}}$ 较小的孔径使得反应气在与催化剂的接触过程中有更 多的停留时间. 不同样品的FTIR结果表明, SC改性提高 了样品中的羟基含量, 而羟基在甲醛催化氧化过程中有 着重要作用 ${ }^{[24]}$. 因此, $\mathrm{HAP}_{\mathrm{SC}}$ 较好的吸附性能、较长的停 留时间以及较高含量的羟基都有利于反应过程中反应 气与催化剂活性位的充分相互作用, 从而提高 $\mathrm{HAP}_{\mathrm{SC}}$ 对 
甲醛的催化氧化活性.

CTAB和SDS常被用作模板剂在合成过程中调控材 料的形貌, 并通过模板剂的去除在结构中产生更多孔

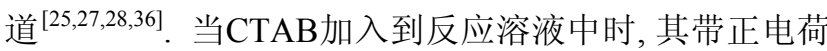
的一端即能附着于HAP上, 同时在合成的HAP中会存在 大量的 $\mathrm{NH}_{4}{ }^{+}$. 在焙烧过程中, $\mathrm{CTAB}$ 有机部分的分解及 铵盐的分解能够在HAP结构中留下孔道 ${ }^{[28]}$. 然而, 由于 $\mathrm{CTAB}$ 有机组成部分及铵盐的分解产生的孔大小不一, 从而导致样品结构的均一性较差 ${ }^{[28]}$. SDS对HAP的改性 及 SDS的分解过程与 CTAB相似 ${ }^{[27]}$. 从 CTAB, SDS和 SC 的结构可知, 高温焙烧时, CTAB和SDS的分解过程中至 少会产生两种气体 $\left(\mathrm{CTAB}\right.$ 产生 $\mathrm{CO}_{2}$ 和 $\mathrm{NH}_{3}, \mathrm{SDS}$ 产生 $\mathrm{CO}_{2}$ 和 $\mathrm{SO}_{2}$ ). 不同大小气体分子的产生会导致孔的均一性较 差. $\mathrm{HAP}_{\mathrm{CTAB}}$ 和 $\mathrm{HAP}_{\mathrm{SDS}}$ 较宽的孔径分布及 $\mathrm{SEM}$ 图都证实 了这一点. 此外, $\mathrm{CTAB}$ 和 SDS 较长的烷基链也导致 $\mathrm{HAP}_{\mathrm{CTAB}}$ 和 $\mathrm{HAP}_{\mathrm{SDS}}$ 样品较大的平均孔径 ${ }^{[37,38]}$. 因此, $\mathrm{HAP}_{\mathrm{CTAB}}$ 和 $\mathrm{HAP}_{\mathrm{SDS}}$ 较大的平均孔径及较差的均一性是
由 CTAB和SDS的结构组成及分解特点决定的. 而对于 $\mathrm{HAP}_{\mathrm{SC}}$, 高温下SC分解产生的大部分为 $\mathrm{CO}_{2}$, 且其较小的 分子也形成了较小的平均孔径.

\section{4. 结论}

不同有机改性剂(CTAB, SDS 和 SC) 对 HAP 的改性 导致了不同样品比表面积及孔结构较为明显的差异, 且 $\mathrm{SC}$ 的改性显著提高了HAP对甲醛催化氧化的催化性能, 在 $240{ }^{\circ} \mathrm{C}$ 实现了甲醛完全转化. $\mathrm{HAP}_{\mathrm{SC}}$ 具有较大的比表 面积、孔体积以及较小的孔径. 较大的比表面积和孔体 积能够提高HAP对甲醛的吸附性能, 同时较小的孔径可 保证反应过程中反应气在催化剂中足够的停留时间. 此 外, 在 $\mathrm{HAP}_{\mathrm{SC}}$ 的结构中还存在更多的羟基, 对甲醛催化氧 化起到了重要的作用. $\mathrm{HAP}_{\mathrm{SC}}$ 较好的吸附性能、较长的 停留时间以及较多含量的羟基都有利于反应过程中反 应气与催化剂活性位的充分相互作用, 从而提高了 $\mathrm{HAP}_{\mathrm{SC}}$ 对甲醛的催化氧化活性. 